training courses in the country - the role was still not formally recognised and the ambulance crews attended the meetihgs voluntarily and in their own time-an indication of the extent of their respect for her.

She was a very effective teacher and provided protected teaching time for her juniors long before the concept was developed. She fought long and hard for one of the early senior registrar posts and had an appreciable formative influence on those who trained with her. She set an example of both patient care and departmental organisation which has served many in their future careers.

At a time when there was a dearth of training in the specialty she set up an annual conference at Windsor which was an important educational event for the developing specialty. She also believed strongly that basic life support skills should be taught in school, even at primary level.

She was committed to accident prevention and road safety, in particular campaigning actively for the introduction of seat belt legislation and the strengthening of drink/drive laws, After her retirement she continued to work for the Road Transport Research Laboratory.

Despite running a busy district general hospital $A \& E$ department single handed she continued to do research throughout her career, producing papers on a range of topics and contributing to the important multicentre study on the effects of seat belt legislation.

She had a clear incisive mind and a strong personality, but never used these to "put down" junior staff. She could be firm with staff and patients but treated all those with whom she came in contact with equality and respect born of a genuine liking for, and enjoyment of, the range of humanity and its idiosyncrasies which are the daily experience of $A \& E$ staff.

She had been in poor health in recent years and following the death of her husband went to Canada to live with her daughter, pressing even at this stage for improvements in the local paramedic services.

She is survived by three children, seven grandchildren, and one great-granddaughter.

S SHANKAR

JANET PORTER

The "Sheila Christian Island Emergency Response Fund" has been established to improve the emergency services in Tancook Island, Nova Scotia. The address for donations is: The "Sheila Christian Island Emergency Response Fund", PO box 47, Tancook Island, Nova Scotia, BOJ3GP, Canada.

\title{
Philip Hedley Brackenbury
}

Philip Hedley Brackenbury (born 1941, qualified Cambridge/Barts 1966) died on 22.8 .97 of multiple myeloma which he had borne courageously since 1989 . He was born the son of a Methodist minister, which meant repeated moves in his early years. This laid the foundation of the Christian faith he was to embrace for himself which directed and sustained him throughout his life. After qualification and junior hospital appointments, he spent two periods working in Mission hospitals, first in Sierra Leone and then in Fiji. Among his many duties there, he was responsible for re-establishing the School of Nursing.

On his return from Service abroad he elected to enter the emerging specialty of accident and emergency medicine and after a short period as a senior registrar was appointed consultant at Middlesborough General Hospital in 1981. There he combined a busy clinical work load with the administrative responsibilities of clinical director. He was keenly involved in training junior staff at $\mathrm{SHO}$ and registrar grade. His experience of training nurses encouraged him to develop clinical nurse practitioner training for the $A \& E$ department. He played a major role in the development of the new A\&E department, coping with the many frustrations that such planning creates. Philip still made time to serve the British Association to Accident and Emergency Medicine as a regional representative on the executive committee and to be a leading member of the A\&E subcommittee of the CCSC. In addition to these duties he took a full part in the breadth of A\&E work, being a representative of the BAEM at the Health Emergency Planning Conference as well as contributing to paramedic training. He brought his caring personality to bear on the problems of child abuse and the difficulties of alcohol misuse. Above all Philip was a hard working and committed Christian doctor.

He married Erica while working at Birmingham Accident Hospital. She shared his life and work in three continents and with their two sons supported him through out his long last illness.

For many of us our lasting memory will be Philip's contribution to the organisation of the BAEM Conference in Durham in 1996 when, despite his poor health, he contributed to the planning and took as full a part as he could. As in all things, Philip enriched everything he did with his sincerity, his gentle humour and his diligent hard work. 